\title{
Analysis of general and specific combining abilities of popcorn populations, including selfed parents
}

\author{
José Marcelo Soriano Viana and Frederico de Pina Matta \\ Universidade Federal de Viçosa, Departamento de Biologia Geral, Viçosa, MG, Brazil.
}

\begin{abstract}
Estimation of general and specific combining ability effects in a diallel analysis of cross-pollinating populations, including the selfed parents, is presented in this work. The restrictions considered satisfy the parametric values of the GCA and SCA effects. The method is extended to self-pollinating populations (suitable for other species, without the selfed parents). The analysis of changes in population means due to inbreeding (sensitivity to inbreeding) also permits to assess the predominant direction of dominance deviations and the relative genetic variability in each parent population. The methodology was used to select popcorn populations for intra- and inter-population breeding programs and for hybrid production, developed at the Federal University of Viçosa, MG, Brazil. Two yellow pearl grain popcorn populations were selected.
\end{abstract}

Key words: diallele cross, combining ability, inbreeding depression, popcorn breeding.

Received: November 21, 2000; Accepted: August 12, 2003.

\section{Introduction}

Diallel analysis of self- and cross-pollinating populations is used to study the genetic control of quantitative traits (Jinks and Hayman, 1953; Hayman, 1954, 1958), to assess general and specific combining abilities (Griffing 1956a, b) and to perform heterosis analysis (Gardner and Eberhart, 1966; Gardner, 1967). It allows to select superior pure lines for hybridization and, in cross-pollinating species, to screen populations for use in intra- and inter-population breeding programs. Griffing's methodology is certainly the most frequently used, because its analysis is easy to perform and to interpret. Gardner and Eberhart's method gives the same information as Griffing's (Cruz and Vencovsky, 1989; Viana, 2000a). Hayman's method is the most complex to understand and to interpret, specifically for homozygous populations. Because of their potentials, these methodologies were adapted for partial diallels, with two groups of parents (Miranda Filho and Geraldi, 1984; Geraldi and Miranda Filho, 1988; Viana et al., 1999).

Regarding cross-pollinating species, the general combining ability (GCA) effect is an indicator of the relative value of the population in terms of frequency of favorable genes and of its divergence, as compared to the other parents in the diallel. Thus, the analysis of GCA effects allows identification of superior parents, to be used in intra-population breeding programs. The specific combin-

Send correspondence to: J.M.S. Viana. E-mail: jmsviana@ufv.br. ing ability (SCA) effect of two populations expresses the differences of gene frequencies between them and their divergence, as compared to the diallel parents. Therefore, the GCA and SCA effects should be considered in the selection of populations for hybrid production and for reciprocal recurrent selection programs. In addition to being indicators of the divergence of each population compared to the diallel parents, the SCA effects of a population with itself allow assessment of the predominant direction of the deviations due to dominance (Cruz and Vencovsky, 1989; Viana, 2000b).

An important information in the selection of a population for a hybrid program is its sensitivity to inbreeding, which can be assessed from a diallel analysis by the inclusion of the selfed parents. In this case, the breeder can assess the genetic variability within each population and the change in the population mean due to inbreeding. The aim of this study is to present a methodology for general and specific combining abilities analysis of a diallel, including the selfed parents. The method will be used to select popcorn maize populations for intra- and inter-population breeding programs and for a hybrid development program, to be carried out at the Federal University of Viçosa, Brazil.

\section{Material and Methods}

We considered the experimental assessment of $\mathrm{N}$ populations, their $\mathrm{N}(\mathrm{N}-1) / 2 \mathrm{~F}_{1}$ hybrids, obtained from the crossing of those populations in a diallel system, and the 
selfed parental populations. The phenotypic means in the diallel table can be defined as follows (Viana, 2000b):

$$
\begin{aligned}
& Y_{j j}=M . .+2 g_{j}+s_{j j}+\bar{e}_{j j} \\
& Y_{j j}=M . .+g_{j}+g_{j}+s_{j j}+\bar{e}_{j j}, \\
& Y_{j j F}=M . .+2 g_{j}+s_{j j}+d_{j F}+\bar{e}_{j j F}
\end{aligned}
$$

where $Y_{\mathrm{jj}}, Y_{\mathrm{j} j}$, and $\mathrm{Y}_{\mathrm{jjF}}$ are, respectively, the means of the jth population, of the hybrid between the jth and j'th populations, and of the $\mathrm{n}$ times selfed jth population $\left(\mathrm{j}, \mathrm{j}^{\prime}=1, \ldots\right.$, $\mathrm{N})$;

$\mathrm{M}_{. .}=\sum_{\mathrm{i}=1}^{\mathrm{k}} \mathrm{m}_{\mathrm{i}}+\sum_{\mathrm{i}=1}^{\mathrm{k}}\left(2 \overline{\mathrm{p}}_{\mathrm{i}}-1\right) \mathrm{a}_{\mathrm{i}}+2 \sum_{\mathrm{i} 1}^{\mathrm{k}} \overline{\mathrm{p}}_{\mathrm{i}}\left(1-\overline{\mathrm{p}}_{\mathrm{i}}\right) \mathrm{d}_{\mathrm{i}} \quad$ is the diallel mean;

$g_{j}=\sum_{i=1}^{k}\left(p_{i j}-\bar{p}_{i}\right)\left[a_{i}+\left(1-2 \bar{p}_{i}\right) d_{i}\right]$ is the GCA effect of the jth population;

$\mathrm{s}_{\mathrm{j} j}=2 \sum_{\mathrm{i}=1}^{\mathrm{k}}\left\{\overline{\mathrm{p}}_{\mathrm{i}}\left(\mathrm{p}_{\mathrm{ij}}-\overline{\mathrm{p}}_{\mathrm{i}}\right)+\overline{\mathrm{p}}_{\mathrm{i}}\left(\mathrm{p}_{\mathrm{ij}}-\overline{\mathrm{p}}_{\mathrm{i}}\right)-\left[\mathrm{p}_{\mathrm{ij}} \mathrm{p}_{\mathrm{ij}},-\left(\overline{\mathrm{p}}_{\mathrm{i}}\right)^{2}\right]\right\} \mathrm{d}_{\mathrm{i}}$

is the SCA effect of the jth and jth populations;

$\mathrm{d}_{\mathrm{jF}}=-2 \mathrm{~F} \sum_{\mathrm{i}=1}^{\mathrm{k}}\left(\mathrm{p}_{\mathrm{ij}}-\mathrm{p}_{\mathrm{ij}}^{2}\right) \mathrm{d}_{\mathrm{i}}$ is the alteration in the genotypic mean of the jth population due to $\mathrm{n}$ generations of selfing, where $\mathrm{F}=1-(1 / 2)^{\mathrm{n}}$ is the inbreeding coefficient;

$\overline{\mathrm{e}}_{\mathrm{j} j}, \overline{\mathrm{e}}_{\mathrm{j} j}$, and $\overline{\mathrm{e}}_{\mathrm{jjF}}$ are the errors associated to observations $\mathrm{Y}_{\mathrm{j} j}$, $\mathrm{Y}_{\mathrm{jj}}$, and $\mathrm{Y}_{\mathrm{jj} \mathrm{j}}$, respectively.

For all loci of the polygenic system under analysis, $\mathrm{m}_{\mathrm{i}}$ is the mean of the genotypic values of the homozygotes, $a_{i}$ is the deviation between the genotypic value of the homozygote with greatest expression and $\mathrm{m}_{\mathrm{i}}$, and $\mathrm{d}_{\mathrm{i}}$ is the deviation due to dominance (Falconer and Mackay, 1996). The $\mathrm{p}_{\mathrm{ij}}$ probability is the frequency in population $\mathrm{j}$ of the locus $i$ gene that increases the trait expression.

The greater the absolute value of $\mathrm{d}_{\mathrm{jF}}$, the closer to $1 / 2$ should be the gene frequencies in the population. Similarly to the $\mathrm{s}_{\mathrm{jj}}$ effects, the changes in the population means due to inbreeding are indicators of the direction of dominance effects. When the mean change is positive, there is negative unidirectional dominance. If inbreeding decreases the genotypic means of the populations (negative $\mathrm{d}_{\mathrm{jF}}$ values), the deviations due to dominance are predominantly positive. Positive and negative $d_{j F}$ values are indicators of bi-directional dominance.

The least squares estimators of the parameters, obtained under the restrictions $\sum_{\mathrm{j}=1}^{\mathrm{N}} \mathrm{g}_{\mathrm{j}}=0$ and $\sum_{\mathrm{j}^{\prime}=1}^{\mathrm{N}} \mathrm{s}_{\mathrm{j} j},=0$, for all $\mathrm{j}$, which satisfy the parametric values of the GCA and SCA effects (Viana, 2000b), are:

$$
\hat{M}_{. .}=\frac{Y_{. \cdot \mathrm{p}}+2 \mathrm{Y}_{\cdot \cdot \mathrm{H}}}{\mathrm{N}^{2}}
$$

where $\mathrm{Y}_{\cdot \cdot \mathrm{P}}=\sum_{\mathrm{j}=1}^{\mathrm{N}} \mathrm{Y}_{\mathrm{jj}}$ and $\mathrm{Y}_{\cdot \cdot \mathrm{H}}=\sum_{\mathrm{j}=1}^{\mathrm{N}} \sum_{<\mathrm{j}^{\prime}=1}^{\mathrm{N}} \mathrm{Y}_{\mathrm{j} \mathrm{j}^{\prime}}$

$$
\begin{aligned}
& \hat{g}_{j}=\bar{Y}_{j \cdot}-\hat{M}_{. .}=\frac{1}{N} \sum_{j^{\prime}=1}^{N} Y_{j j}-\hat{M}_{. .} \\
& \hat{s}_{j j}=Y_{j j}-\hat{M}_{. .}-2 \hat{g}_{j} \\
& \hat{s}_{j j}=Y_{j j},-\hat{M}_{. .}-\hat{g}_{j}-\hat{g}_{j}, \\
& \hat{d}_{j F}=Y_{j j F}-Y_{j j}
\end{aligned}
$$

If the parents were selfed only once $(F=1 / 2)$, the estimator of the mean of the inbred lines which may be obtained from a population without selection is

$$
\mathrm{M}_{\mathrm{jjF}=1}=\mathrm{Y}_{\mathrm{jj}}+2 \hat{\mathrm{d}}_{\mathrm{jF}=1 / 2}=2 \mathrm{Y}_{\mathrm{jjF}=1 / 2}-\mathrm{Y}_{\mathrm{jj}}
$$

The sampling variances of the estimators of the parameters and of the differences between effects are:

$$
\hat{\mathrm{V}}\left(\hat{\mathrm{M}}_{. .}\right)=\left(\frac{2 \mathrm{~N}-1}{\mathrm{~N}^{3}}\right)\left(\frac{\hat{\sigma}^{2}}{\mathrm{r}}\right)
$$

where $\hat{\sigma}^{2}$ is the mean square of error of the variance analysis, and $r$ is the number of replications,

$$
\begin{aligned}
& \hat{\mathrm{V}}\left(\hat{\mathrm{g}}_{\mathrm{j}}\right)=\left(\frac{(\mathrm{N}-1)^{2}}{\mathrm{~N}^{3}}\right)\left(\frac{\hat{\sigma}^{2}}{\mathrm{r}}\right) \\
& \hat{\mathrm{V}}\left(\hat{\mathrm{g}}_{\mathrm{j}}-\hat{\mathrm{g}}_{\mathrm{j}^{\prime}}\right)=\left(\frac{2(\mathrm{~N}-1)}{\mathrm{N}^{2}}\right)\left(\frac{\hat{\sigma}^{2}}{\mathrm{r}}\right) \\
& \hat{\mathrm{V}}\left(\hat{\mathrm{s}}_{\mathrm{jj}}\right)=\left(\frac{\left(\mathrm{N}^{3}-4 \mathrm{~N}+3\right)}{\mathrm{N}^{3}}\right)\left(\frac{\hat{\sigma}^{2}}{\mathrm{r}}\right) \\
& \hat{\mathrm{V}}\left(\hat{\mathrm{s}}_{\mathrm{jj}}-\hat{\mathrm{s}}_{\mathrm{j}^{\prime} \mathrm{j}^{\prime}}\right)=\left(\frac{2\left(\mathrm{~N}^{2}-4\right)}{\mathrm{N}^{2}}\right)\left(\frac{\hat{\sigma}^{2}}{\mathrm{r}}\right) \\
& \hat{\mathrm{V}}\left(\hat{\mathrm{s}}_{\mathrm{j} j^{\prime}}\right)=\left(\frac{\left(\mathrm{N}^{3}-2 \mathrm{~N}^{2}+3\right)}{\mathrm{N}^{3}}\right)\left(\frac{\hat{\sigma}^{2}}{\mathrm{r}}\right) \\
& \hat{\mathrm{V}}\left(\hat{\mathrm{s}}_{\mathrm{jj}}-\hat{\mathrm{s}}_{\mathrm{jj},}\right)=\left(\frac{2\left(\mathrm{~N}^{2}-\mathrm{N}-1\right)}{\mathrm{N}^{2}}\right)\left(\frac{\hat{\sigma}^{2}}{\mathrm{r}}\right) \\
& \hat{\mathrm{V}}\left(\hat{\mathrm{s}}_{\mathrm{jj},}-\hat{\mathrm{s}}_{\mathrm{j}, \mathrm{j}^{\prime \prime},}\right)=\left(\frac{2\left(\mathrm{~N}^{2}-2 \mathrm{~N}-2\right)}{\mathrm{N}^{2}}\right)\left(\frac{\hat{\sigma}^{2}}{\mathrm{r}}\right) \\
& \hat{\mathrm{V}}\left(\hat{\mathrm{d}}_{\mathrm{jF}}\right)=2\left(\frac{\hat{\sigma}^{2}}{\mathrm{r}}\right) \\
& \hat{\mathrm{V}}\left(\hat{\mathrm{d}}_{\mathrm{jF}}-\hat{\mathrm{d}}_{\mathrm{j}^{\prime} \mathrm{F}}\right)=4\left(\frac{\hat{\sigma}^{2}}{\mathrm{r}}\right)
\end{aligned}
$$

The following hypotheses can be tested in the variance analysis of the diallel table:

- $\mathrm{H}_{0(1)}: \mathrm{g}_{\mathrm{j}}=0$ for all $\mathrm{j}$. Its rejection indicates differences in gene frequencies between the parents in the diallel; 
- $\mathrm{H}_{0(2)}: \mathrm{s}_{\mathrm{jj}}=0$ for all $\mathrm{j}$ and $\mathrm{j}$ '. If there is genetic variability between the parents, its rejection indicates the presence of dominance;

$\cdot \mathrm{H}_{0(3)}: \mathrm{p}_{\mathrm{ij}}=1$ or $\mathrm{p}_{\mathrm{ij}}=0$ for all $\mathrm{i}\left(\mathrm{d}_{\mathrm{jF}}=0\right.$ for all $\left.\mathrm{j}\right)$. If there is dominance, testing this hypothesis is equivalent to test for no genetic variability in each parent population.

Let

$\beta^{\prime}=\left[\mathrm{M}_{. .}: \mathrm{g}_{1} \cdots \mathrm{g}_{\mathrm{N}} \vdots \mathrm{s}_{11} \mathrm{~s}_{12} \cdots \mathrm{s}_{1 \mathrm{~N}} \cdots \mathrm{s}_{\mathrm{NN}} \vdots \mathrm{d}_{1 \mathrm{~F}} \cdots \mathrm{d}_{\mathrm{NF}}\right]=[\mu: \mathrm{g}: \mathrm{s}: \mathrm{d}]$

be the parameter vector, $\mathrm{R}($.) the reduction in the total sum of squares due to fitting a certain model, and R(. . .) a difference between two R(.) terms (Searle, 1971; Graybill, 1976). The sum of squares attributable to hypothesis $\mathrm{H}_{0(1)}$ (GCA sum of squares) is

$\mathrm{R}(\mathrm{g} \mid \mu, \mathrm{s}, \mathrm{d})=\mathrm{R}(\mu, \mathrm{g}, \mathrm{s}, \mathrm{d})-\mathrm{R}(\mu, \mathrm{s}, \mathrm{d})$, with $\mathrm{N}-1$ degrees of freedom, where:

$R(\mu, g, s, d)=r\left(\sum_{j=1}^{N} Y_{j j F}^{2}+\sum_{j=1}^{N} \sum_{\leq j^{\prime}=1}^{N} Y_{j j^{\prime}}^{2}\right)$ is the parameter sum of squares of the complete model;

$R(\mu, s, d)=r\left[\hat{M}_{. .}\left(Y_{. \cdot F}+Y_{. . p}+Y_{\cdot \cdot H}\right)+\sum_{j=1}^{N} \hat{s}_{j j}\left(Y_{j j F}+Y_{j j}\right)+\right.$ $\left.\sum_{j=1}^{N} \sum_{<j^{\prime}=1}^{N} \hat{s}_{j j}, Y_{j j},+\sum_{j=1}^{N} \hat{d}_{j F} Y_{j j F}\right]$ is the parameter sum of squares of the complete model reduced by the $\mathrm{H}_{0(1)}$ hypothesis, given $\mathrm{Y}_{\cdot \mathrm{F}}=\sum_{\mathrm{j}=1}^{\mathrm{N}} \mathrm{Y}_{\mathrm{j \textrm {j }} \mathrm{F}}$, and further,

$$
\begin{aligned}
& \hat{M}_{. .}=\frac{Y_{. \cdot p}+2 Y_{\cdot \cdot H}}{N^{2}} \\
& \hat{s}_{j j}=Y_{j j}-\bar{Y}_{j \cdot} \\
& \hat{s}_{j j}=Y_{j j}-\bar{Y}_{j \cdot}-\bar{Y}_{j \cdot \cdot}+\hat{M}_{. \cdot} \\
& \hat{d}_{j F}=Y_{j j F}-\hat{M}_{. .}-\hat{s}_{j j}
\end{aligned}
$$

The sum of squares attributable to hypothesis $\mathrm{H}_{0(2)}$ (SCA sum of squares) is the same as that of Griffing's model (1956b), given by

$\mathrm{R}(\mathrm{s} \mid \mu, \mathrm{g}, \mathrm{d})=\mathrm{r}\left[\sum_{\mathrm{j}=1}^{\mathrm{N}} \sum_{\leq \mathrm{j}^{\prime}=1}^{\mathrm{N}} \mathrm{Y}_{\mathrm{j} j^{2}},-\frac{1}{\mathrm{~N}+2} \sum_{\mathrm{j}=1}^{\mathrm{N}}\left(\mathrm{Y}_{\mathrm{jj}}+\mathrm{Y}_{\mathrm{j}}\right)^{2}+\right.$ $\left.\frac{2\left(\mathrm{Y}_{. \cdot \mathrm{P}}+\mathrm{Y}_{\cdot \cdot \mathrm{H}}\right)^{2}}{(\mathrm{~N}+1)(\mathrm{N}+2)}\right]$, with $\mathrm{N}(\mathrm{N}-1) / 2$ degrees of freedom

The sum of squares attributable to hypothesis $\mathrm{H}_{0(3)}$ (sum of squares due to inbreeding) is

$\mathrm{R}(\mathrm{d} \mid \mu, \mathrm{g}, \mathrm{s})=\mathrm{R}(\mu, \mathrm{g}, \mathrm{s}, \mathrm{d})-\mathrm{R}(\mu, \mathrm{g}, \mathrm{s})$, with $\mathrm{N}$ degrees of freedom, where:

$$
r\left[\hat{M}_{. .}\left(Y_{\cdot * F}+Y_{. \cdot p}+Y_{\cdot \cdot H}\right)+\sum_{j=1}^{N} \hat{g}_{j}\left(2 Y_{j j F}+Y_{j j}+Y_{j} .\right)+\right.
$$

$\left.\sum_{j=1}^{N} \hat{s}_{j j}\left(Y_{j j F}+Y_{j j}\right)+\sum_{j=1}^{N} \sum_{<j^{\prime}=1}^{N} \hat{s}_{j j}, Y_{j j}\right]=R(\mu, g, s)$ is the param-

eter sum of squares of the complete model reduced by the $\mathrm{H}_{0(3)}$ hypothesis, and further,

$$
\begin{aligned}
& \hat{M}_{. .}=\frac{Y_{. \cdot F}+Y_{. \cdot P}+4 Y_{\cdot \cdot H}}{2 N^{2}} \\
& \hat{g}_{j}=\frac{1}{N}\left[Y_{j \cdot}+\left(\frac{Y_{j j F}-Y_{j j}}{2}\right)\right]-\hat{M}_{. \cdot} \\
& \hat{s}_{j j}=\frac{Y_{j j F}+Y_{j j}}{2}-\hat{M}_{. .}-2 \hat{g}_{j} \\
& \hat{s}_{j j}=Y_{j j}-\hat{M}_{. .}-\hat{g}_{j}-\hat{g}_{j},
\end{aligned}
$$

Due to inclusion of the selfed parents, the sum of squares attributable to the hypothesis of absence of dominance $\left(d_{i}=0\right.$ for all $\left.i\right)$ is not the SCA sum of squares. Its value is given by the following expression:

$\mathrm{R}(\mathrm{s}, \mathrm{d} \mid \mu, \mathrm{g})=\mathrm{R}(\mu, \mathrm{g}, \mathrm{s}, \mathrm{d})-\mathrm{R}(\mu, \mathrm{g})$, with $\mathrm{N}(\mathrm{N}+1) / 2$ degrees of freedom, where:

$R(\mu, g)=r\left[\frac{\left(Y_{\cdot \cdot F}+Y_{\cdot \cdot P}+Y_{\cdot \cdot H}\right)^{2}}{N+\frac{N(N+1)}{2}}+\sum_{j=1}^{N} \hat{g}_{j}\left(2 Y_{j j F}+Y_{j j}+Y_{j \cdot}\right)\right]$,

given

$\hat{g}_{j}=\frac{1}{N+6}\left[2 Y_{j j F}+Y_{j j}+Y_{j \cdot}-(N+3) \frac{\left(Y_{\cdot \cdot F}+Y_{\cdot \cdot \cdot \mathrm{P}}+Y_{\cdot \cdot H}\right)}{N+\frac{N(N+1)}{2}}\right]$

For analysis only with parents and hybrids, the estimators of the GCA and SCA effects and of the variances of the effect and contrast estimators are the same as already presented. The parameter sum of squares of the complete model is

$$
\mathrm{R}(\mu, \mathrm{g}, \mathrm{s})=\mathrm{r}\left(\sum_{\mathrm{j}=1}^{\mathrm{N}} \sum_{\leq \mathrm{j}^{\prime}=1}^{\mathrm{N}} \mathrm{Y}_{\mathrm{j} \mathrm{j}^{\prime}}^{2}\right)
$$

The sum of squares attributable to hypothesis $\mathrm{H}_{0(1)}$ (GCA sum of squares) is $\mathrm{R}(\mathrm{g} \mid \mu, \mathrm{s})=\mathrm{R}(\mu, \mathrm{g}, \mathrm{s})-\mathrm{R}(\mu, \mathrm{s})$, with $\mathrm{N}-1$ degrees of freedom, where

$$
R(\mu, s)=r\left[\hat{M}_{. .}\left(Y_{. . P}+Y_{\cdot \cdot H}\right)+\sum_{j=1}^{N} \sum_{\leq j=1}^{N} \hat{s}_{i j}, Y_{j j}\right] \text { is the }
$$

parameter sum of squares of the complete model reduced by the $\mathrm{H}_{0(1)}$ hypothesis, given

$$
\begin{aligned}
& \hat{M}_{. .}=\frac{Y_{. . P}+2 Y_{. \cdot H}}{N^{2}} \\
& \hat{s}_{j j}=Y_{j j}-\bar{Y}_{j} .
\end{aligned}
$$


$\hat{s}_{\mathrm{jj}},=\mathrm{Y}_{\mathrm{jj}},-\overline{\mathrm{Y}}_{\mathrm{j} \cdot}-\overline{\mathrm{Y}}_{\mathrm{j}, \cdot}+\hat{\mathrm{M}}_{. .}$

The SCA sum of squares is the same as presented above. If there is genetic variability between the parents, it corresponds to the sum of squares attributable to the hypothesis of absence of dominance.

The previously described method was applied to a diallel with popcorn maize populations from the breeding program of the Genetic Sector of the Department of General Biology of the Federal University of Viçosa, MG, Brazil. The populations were: Rosa Claro, with red pearl grains; Branco, with white pearl grains; Roxo, with red pearl grains; Amarelo, Beija-Flor and Viçosa, all with yellow pearl grains. Beija-Flor also has colored and white grains and garlic-type grains. Pollination was carried out in the 95/96 season, and the parents, the selfed parents and the $F_{1}$ were experimentally assessed in 96/97 at Viçosa, MG. The expansion volume $(\mathrm{EV}=$ popcorn volume/grain weight) of the populations was assessed in a Hot Air Popcorn Pumper H7340 (1,250 W; 60 Hz) from Proctor Silex, and in the popcorn machine of the National Maize and Sorghum Research Center - CNPMS/Embrapa.

\section{Results and Discussion}

\section{Expansion volume analysis}

The joint diallel analysis showed that the differences between the GCA effects of two populations and between the SCA effects of the populations or hybrids were not constant for the two popcorn machines (Table 1). The difference between the changes in the means of two populations also varied from one to the other. Due to the interaction, a separated diallel analysis was made for each system. They showed differences between the GCA and SCA effects and between the changes in the means due to inbreeding (Table 2).
Table 1 - Joint diallel analysis of expansion volume data $(\mathrm{mL} / \mathrm{g})$ of six popcorn populations, their hybrids and selfed parents, obtained using a hot air popcorn machine and the CNPMS/Embrapa popcorn machine.

\begin{tabular}{lcccc}
\hline SV & df & SS & MS & Prob. \\
\hline Poppers & 1 & 0.33 & 0.33 & 0.51 \\
Populations & $(26)$ & $(784.01)$ & 30.15 & $1.30 \mathrm{E}-26$ \\
GCA & 5 & 308.30 & 61.66 & $6.77 \mathrm{E}-24$ \\
SCA & 15 & 217.50 & 14.50 & $2.06 \mathrm{E}-16$ \\
Inbreeding & 6 & 107.52 & 17.92 & $1.69 \mathrm{E}-13$ \\
Pop. x Poppers & $(26)$ & $(81.41)$ & 3.13 & $5.36 \mathrm{E}-06$ \\
GCA x Poppers & 5 & 31.78 & 6.36 & $6.36 \mathrm{E}-06$ \\
SCA x Poppers & 15 & 32.72 & 2.18 & $2.25 \mathrm{E}-03$ \\
Inbr. x Poppers & 6 & 16.08 & 2.68 & $5.03 \mathrm{E}-03$ \\
Error & 54 & 40.91 & 0.76 & \\
\hline
\end{tabular}

Based on data obtained with the hot air popcorn machine, Beija-Flor (24.08) and Branco (24.59) populations were found to be superior in terms of frequency of favorable genes and divergent regarding the mean frequencies of the parent group (Table 3 ). The positive $\mathrm{s}_{\mathrm{jj}}$ estimates indicate that the genes with some degree of dominance acted so as to reduce the expansion volume (Table 4). The populations with the greatest differences in gene frequencies between each other and in relation to the parent group were Rosa Claro and Beija-Flor. They, however, did not produce the best hybrids, possibly due to negative heterosis. The best hybrids were Roxo x Beija-Flor (22.75), Branco x Beija-Flor (21.97), and Beija-Flor x Viçosa (20.24). Roxo and Beija-Flor are populations with small differences in gene frequency, but they are divergent as compared to the parents of the diallel. Branco and Amarelo, and Branco and Viçosa diverged little from each other and from the mean frequencies of the parent group (Table 4).

Table 2 - Diallel analysis of expansion volume (EV, $\mathrm{mL} / \mathrm{g}$ ), yield ( $\mathrm{kg} / \mathrm{ha})$, plant height $(\mathrm{PH}, \mathrm{m})$, ear height $(\mathrm{EH}, \mathrm{m})$, proportion of root lodged plants (RL), proportion of stalk lodged plants (SL), prolificacy index (PI), and one hundred grains weight (100GW, g), of six popcorn populations, their hybrids and selfed parents, and estimates of the diallel mean and its standard deviation.

\begin{tabular}{|c|c|c|c|c|c|c|c|c|c|c|}
\hline \multirow[t]{2}{*}{ SV } & \multirow[t]{2}{*}{ df } & \multicolumn{9}{|c|}{ MS } \\
\hline & & $\mathrm{EV}^{1}$ & $\mathrm{EV}^{2}$ & Yield & $\mathrm{PH}$ & $\mathrm{EH}$ & RL & SL & PI & $100 \mathrm{GW}$ \\
\hline Blocks & 1 & - & - & 10238640.00 & 0.002 & 0.061 & 0.030 & 0.028 & $1 \times 10^{-5}$ & 6.85 \\
\hline Populations & (26) & $18.37^{* *}$ & $14.90^{* *}$ & $12020756.80^{* *}$ & $0.108^{* *}$ & $0.025^{* *}$ & $0.007^{*}$ & $0.034^{* *}$ & $0.101^{*}$ & $9.19^{\mathrm{ns}}$ \\
\hline GCA & 5 & $35.39^{* *}$ & $32.62^{* *}$ & $12918488.60^{* *}$ & $0.103^{* *}$ & $0.032^{* *}$ & $0.004^{\mathrm{ns}}$ & $0.007^{* *}$ & $0.089^{\mathrm{ns}}$ & $11.80^{\mathrm{ns}}$ \\
\hline SCA & 15 & $9.77^{* *}$ & $6.91^{* *}$ & $6332106.13^{* *}$ & $0.035^{\mathrm{ns}}$ & $0.008^{\mathrm{ns}}$ & $0.002^{\mathrm{ns}}$ & $0.003^{\mathrm{ns}}$ & $0.059^{\mathrm{ns}}$ & $3.89^{\mathrm{ns}}$ \\
\hline Inbreeding & 6 & $11.05^{* *}$ & $9.55^{* *}$ & $12745139.50^{* *}$ & $0.131^{* *}$ & $0.019^{*}$ & $0.017^{* *}$ & $0.072^{\mathrm{ns}}$ & $0.086^{\mathrm{ns}}$ & $14.51^{*}$ \\
\hline Error & $26\left(54^{3}\right)$ & 0.76 & 0.76 & 1801646.00 & 0.025 & 0.007 & 0.003 & 0.008 & 0.043 & 5.71 \\
\hline$\hat{\mathrm{M}}_{.}$ & & 18.50 & 18.77 & 4972.09 & 1.59 & 0.74 & 0.103 & 0.111 & 0.96 & 16.26 \\
\hline$\hat{\mathrm{s}}\left(\hat{\mathrm{M}}_{. .}\right)$ & & 0.14 & 0.14 & 214.19 & 0.03 & 0.01 & $8.9 \mathrm{E}-03$ & 0.014 & 0.03 & 0.38 \\
\hline
\end{tabular}

${ }^{1}$ data obtained using the hot air popcorn machine; ${ }^{2}$ data obtained using the CNPMS/Embrapa popcorn machine; ${ }^{3}$ For the EV analyses; ${ }^{* *}: \mathrm{F}<0.01$; *: $0.01<\mathrm{F}<0.05 ;{ }^{\text {ns }}$ : $\mathrm{F}>0.05$. 
Similar inferences can be made from the analysis of data obtained using the CNMS/Embrapa popcorn machine. Beija-Flor (24.08), Branco (19.63) and Viçosa (23.92) stood out as populations with superior frequencies of the desirable genes and divergent as compared to the mean frequencies in the parents of the diallel (Table 3). The estimated $\mathrm{s}_{\mathrm{jj}}$ values also showed deviations due to dominance, predominantly negative (Table 4 ). The populations which

Table 3 - Estimates of general combining ability effects of popcorn populations for expansion volume (EV, $\mathrm{mL} / \mathrm{g}$ ), yield ( $\mathrm{kg} / \mathrm{ha}$ ), plant height (PH, $\mathrm{m}$ ), ear height $(\mathrm{EH}, \mathrm{m})$, proportion of root lodged plants (RL), proportion of stalk lodged plants (SL) and prolificacy index (PI), and standard deviation estimates of the effects and contrasts.

\begin{tabular}{lrrrrrrrr}
\hline Population & $\mathrm{EV}^{1}$ & $\mathrm{EV}^{2}$ & Yield & EH & PH & RL & \multicolumn{1}{c}{ SL } & PI \\
\hline Rosa Claro & -1.73 & -1.23 & 537.24 & 0.06 & 0.01 & 0.009 & 0.020 & 0.14 \\
Branco & 1.63 & 0.90 & -1604.63 & -0.16 & -0.08 & 0.019 & 0.010 & -0.09 \\
Roxo & -0.21 & -1.72 & 623.23 & 0.05 & 0.04 & -0.009 & -0.021 & 0.06 \\
Amarelo & -1.78 & -1.36 & 606.91 & 0.09 & 0.06 & -0.031 & -0.025 & -0.02 \\
Beija-Flor & 2.41 & 2.29 & -1016.59 & -0.05 & -0.04 & 0.013 & 0.030 & -0.08 \\
Viçosa & -0.32 & 1.12 & 853.83 & 0.003 & 0.01 & -0.001 & -0.015 & -0.01 \\
\hline$\hat{\mathrm{s}}\left(\hat{\mathrm{g}}_{\mathrm{j}}\right)$ & 0.21 & 0.21 & 322.90 & 0.04 & 0.02 & $1.3 \mathrm{E}-02$ & 0.021 & 0.05 \\
$\hat{\mathrm{s}}\left(\hat{\mathrm{g}}_{\mathrm{j}}-\hat{\mathrm{g}}_{\mathrm{j}}\right)$ & 0.32 & 0.32 & 500.23 & 0.06 & 0.03 & $2.1 \mathrm{E}-02$ & 0.033 & 0.08 \\
\hline
\end{tabular}

${ }^{1}$ data obtained using the hot air popcorn machine; ${ }^{2}$ data obtained using the CNPMS/Embrapa popcorn machine.

Table 4 - Estimates of specific combining ability effects of popcorn populations for expansion volume (EV, mL/g), yield (kg/ha), plant height (PH, $\mathrm{m}$ ), ear height $(\mathrm{EH}, \mathrm{m})$, proportion of root lodged plants (RL), proportion of stalk lodged plants (SL) and prolificacy index (PI), and standard deviation estimates of the effects and contrasts.

\begin{tabular}{|c|c|c|c|c|c|c|c|c|}
\hline Populations $^{1}$ & $\mathrm{EV}^{2}$ & $\mathrm{EV}^{3}$ & Yield & EH & $\mathrm{PH}$ & RL & SL & PI \\
\hline $1 \times 1$ & 3.58 & 2.53 & 2266.69 & 0.02 & -0.03 & 0.009 & -0.032 & -0.03 \\
\hline $2 \times 2$ & 2.83 & -0.93 & -733.03 & -0.19 & -0.08 & 0.039 & -0.022 & -0.003 \\
\hline $3 \times 3$ & 0.01 & -0.10 & -3047.15 & -0.09 & -0.07 & -0.004 & 0.031 & -0.40 \\
\hline $4 \times 4$ & 2.54 & 3.26 & -3595.46 & -0.21 & -0.11 & -0.011 & 0.028 & -0.32 \\
\hline $5 \times 5$ & 0.76 & 0.74 & 597.81 & 0.11 & 0.01 & -0.068 & -0.082 & 0.04 \\
\hline $6 \times 6$ & 5.03 & 2.91 & -1819.34 & -0.003 & -0.001 & 0.009 & 0.018 & -0.08 \\
\hline $1 \times 2$ & 0.21 & -0.35 & -232.01 & 0.01 & 0.02 & -0.041 & -0.022 & 0.02 \\
\hline $1 \times 3$ & 0.71 & 1.46 & -1124.35 & -0.09 & -0.02 & -0.013 & -0.030 & -0.001 \\
\hline $1 \times 4$ & -0.73 & 0.07 & -414.75 & -0.03 & -0.02 & 0.039 & 0.013 & 0.05 \\
\hline $1 \times 5$ & -2.90 & -2.61 & 233.26 & 0.05 & 0.02 & 0.006 & 0.078 & -0.03 \\
\hline $1 \times 6$ & -0.86 & -1.10 & -728.84 & 0.04 & 0.03 & -0.001 & -0.007 & -0.005 \\
\hline $2 \times 3$ & -1.50 & -0.46 & 1478.32 & 0.14 & 0.06 & -0.013 & -0.0003 & 0.19 \\
\hline $2 \times 4$ & -0.49 & -0.85 & 221.48 & 0.16 & 0.04 & -0.021 & -0.017 & 0.04 \\
\hline $2 \times 5$ & -0.57 & 0.43 & -846.17 & -0.21 & -0.06 & 0.046 & 0.048 & -0.18 \\
\hline $2 \times 6$ & -0.48 & 2.16 & 111.41 & 0.09 & 0.02 & -0.011 & 0.013 & -0.07 \\
\hline $3 \times 4$ & -0.12 & -0.39 & 221.69 & 0.14 & 0.13 & -0.003 & 0.005 & -0.07 \\
\hline $3 \times 5$ & 2.05 & 1.77 & 920.34 & -0.09 & -0.05 & 0.034 & -0.0003 & 0.22 \\
\hline $3 \times 6$ & -1.14 & -2.28 & 1551.15 & -0.004 & -0.04 & -0.002 & -0.005 & 0.06 \\
\hline $4 \times 5$ & 1.01 & -0.37 & 888.09 & 0.11 & 0.03 & -0.014 & -0.027 & 0.08 \\
\hline $4 \times 6$ & -2.20 & -1.72 & 2678.95 & -0.16 & -0.07 & 0.009 & -0.002 & 0.22 \\
\hline $5 \times 6$ & -0.35 & 0.04 & -1793.33 & 0.04 & 0.05 & -0.004 & -0.017 & -0.12 \\
\hline$\hat{\mathrm{s}}\left(\hat{\mathrm{s}}_{\mathrm{jj}}\right)$ & 0.58 & 0.58 & 901.80 & 0.11 & 0.06 & $3.7 \mathrm{E}-02$ & 0.060 & 0.14 \\
\hline$\hat{\mathrm{s}}\left(\hat{\mathrm{s}}_{\mathrm{j} j}-\hat{\mathrm{s}}_{\mathrm{j}^{\prime} \mathrm{j}^{\prime}}\right)$ & 0.82 & 0.82 & 1265.49 & 0.15 & 0.08 & $5.2 \mathrm{E}-02$ & 0.084 & 0.20 \\
\hline$\hat{\mathrm{s}}\left(\hat{\mathrm{s}}_{\mathrm{j} j}\right)$ & 0.51 & 0.51 & 782.98 & 0.09 & 0.05 & $3.2 \mathrm{E}-02$ & 0.052 & 0.12 \\
\hline$\hat{\mathrm{s}}\left(\hat{\mathrm{s}}_{\mathrm{j} j},-\hat{\mathrm{s}}_{\mathrm{j} \mathrm{j},},\right)$ & 0.78 & 0.78 & 1204.71 & 0.14 & 0.08 & $5.0 \mathrm{E}-02$ & 0.080 & 0.19 \\
\hline$\hat{\mathrm{s}}\left(\hat{\mathrm{s}}_{\mathrm{j} j},-\hat{\mathrm{s}}_{\mathrm{j}, \mathrm{j}, \mathrm{j},}\right)$ & 0.68 & 0.68 & 1049.29 & 0.12 & 0.07 & 4.4E- 02 & 0.069 & 0.16 \\
\hline
\end{tabular}

${ }^{1} 1=$ Rosa Claro, $2=$ Branco, $3=$ Roxo, $4=$ Amarelo, $5=$ Beija-Flor and $6=$ Viçosa $;{ }^{2}$ data obtained using the hot air popcorn machine; ${ }^{3}$ data obtained using the CNPMS/Embrapa popcorn machine. 
diverged most both from the parents and between each other were Rosa Claro and Beija-Flor, and Roxo and Viçosa. They did not produce outstanding hybrids either. The best hybrids were Branco x Viçosa (22.94), Branco x Beija-Flor (22.38), and Beija-Flor x Viçosa (22.21). Roxo and Beija-Flor, and Rosa Claro and Roxo differed little in gene frequency, but they were divergent as compared to the mean frequencies in the parents. Rosa Claro and Branco, and Amarelo and Beija-Flor diverged little between each other and with regard to the parent group (Table 4).

The analysis of alterations due to inbreeding in both assessment systems indicated the presence of bi-directional dominance (positive and negative dominance deviations), less genetic variability (gene frequencies closer to 1 or 0 ) in the Beija-Flor population, and greater sensitivity to inbreeding (gene frequencies closer to $1 / 2$ ) in the Viçosa population, which is a source of desirable dominant genes for increased expansion volume (Table 5). Regarding the hot air popcorn machine, the estimates of the mean of the inbred lines which can be obtained from the Beija-Flor, Branco and Viçosa populations were, respectively, 24.08, 17.57, and 12.23. The corresponding values for the CNPMS/Embrapa popcorn machine were 23.24, 21.83, and 14.92.

\section{Yield analysis}

Variance analysis showed genetic variability between and within populations, and due to dominance gene action (Table 2). The populations found to be superior in terms of frequency of the genes which increase yield and divergent as compared to the parent group were Viçosa (4860.4), Roxo (3171.4), and Amarelo (2590.5) (Table 3). The $\mathrm{s}_{\mathrm{jj}}$ estimates indicated that the dominant genes act predominantly to increase yield (Table 4). The two most productive hybrids were Amarelo x Viçosa (9111.8) and Roxo x Viçosa (8000.3). They are derived from populations with the greatest differences in gene frequencies from the parent group and between each other, and the superior yield is cer- tainly due to high heterosis. Beija-Flor (3536.7) and Viçosa, and Rosa Claro and Roxo have small gene frequency differences, but are divergent as compared to the mean frequencies of the diallel parents. The populations with the lowest divergence from the mean frequencies of the parent group and between each other were Roxo and Amarelo, and Branco and Amarelo (Table 4). The estimates of changes in the population mean due to inbreeding also indicated the presence of positive unidirectional dominance (Table 5). Inbreeding depression was observed in all the populations, especially in Rosa Claro and Viçosa. The least sensitive population was Branco, and, compared to the others, the gene frequencies in this population were closer to 1 or to 0 .

The means of Beija-Flor x Viçosa and Branco $\mathrm{x}$ Viçosa hybrids, which include a population superior in quality and a population superior in quality and yield, were $3016 \mathrm{~kg} / \mathrm{ha}$ and $4332.7 \mathrm{~kg} / \mathrm{ha}$, respectively, indicating good yield potential. These hybrids have equivalent expansion volumes, with means of 20.24 and 19.33 in the hot air popcorn machine, and 22.21 and 22.94 in the CNPMS/Embrapa popcorn machine, respectively.

\section{Analyses of plant height, ear height, proportion of root lodged plants, proportion of stalk lodged plants, prolificacy index, and one hundred grains weight}

With regard to plant and ear height, variance analysis indicated the presence of genetic variability between populations, significant differences between the GCA effects, nullity of SCA effects, and genetic variability within parent populations (Table 2). Significance tests for changes in the means due to inbreeding can be carried out, once there is dominance, as indicated by the test of hypothesis $\mathrm{H}_{0}$ : $\mathrm{d}_{\mathrm{i}}=0$ for all $i$. The F statistics values were 3.78 (significant at the $1 \%$ level of probability) for plant height and 2.56 (significant at $5 \%$ ) for ear height. The analysis of the GCA effects estimates showed that $\mathrm{Branco}(\mathrm{PH}=1.08$ and $\mathrm{EH}=0.50)$ and Beija-Flor $(\mathrm{PH}=1.60$ and $\mathrm{EH}=0.67)$ were sources of

Table 5 - Estimates of changes in the genotypic means of popcorn populations for expansion volume (EV, mL/g) ${ }^{1}, \mathrm{yield}(\mathrm{kg} / \mathrm{ha})$, plant height (PH, $\left.\mathrm{m}\right)$, ear height $(\mathrm{EH}, \mathrm{m})$, proportion of root lodged plants (RL), proportion of stalk lodged plants (SL) and prolificacy index (PI), and standard deviation estimates of the effects and contrasts.

\begin{tabular}{lrrrrrrrr}
\hline Population & $\mathrm{EV}^{1}$ & $\mathrm{EV}^{2}$ & Yield & EH & PH & RL & SL & PI \\
\hline Rosa Claro & 4.69 & 3.56 & -7004.26 & -0.77 & -0.27 & 0.190 & 0.210 & -0.55 \\
Branco & -3.51 & 1.10 & -689.58 & -0.11 & -0.04 & -0.180 & 0.620 & -0.11 \\
Roxo & 1.60 & 4.27 & -2381.60 & -0.36 & -0.17 & 0.090 & 0.030 & -0.25 \\
Amarelo & -1.01 & -2.18 & -1417.39 & -0.17 & -0.06 & 0.150 & 0.020 & 0.05 \\
Beija-Flor & 0.00 & -0.42 & -2903.06 & -0.06 & 0.03 & 0.020 & 0.040 & -0.36 \\
Viçosa & -5.33 & -4.50 & -3290.43 & -0.13 & -0.07 & 0.050 & 0.030 & -0.09 \\
\hline$\hat{\mathrm{s}}\left(\hat{\mathrm{d}}_{\mathrm{jF}}\right)$ & 0.87 & 0.87 & 1342.25 & 0.16 & 0.09 & $5.6 \mathrm{E}-02$ & 0.089 & 0.21 \\
$\hat{\mathrm{s}}\left(\hat{\mathrm{d}}_{\mathrm{jF}}-\hat{\mathrm{d}}_{\mathrm{j} \text { ' F }}\right)$ & 1.23 & 1.23 & 1898.23 & 0.22 & 0.12 & $7.9 \mathrm{E}-02$ & 0.126 & 0.29 \\
\hline
\end{tabular}

${ }^{1}$ data obtained using the hot air popcorn machine; ${ }^{2}$ data obtained using the CNPMS/Embrapa popcorn machine. 
genes for short plant height and reduced upper ear insertion height. Genes for tall plants and high upper ear insertion were more frequent in Roxo $(\mathrm{PH}=1.61$ and $\mathrm{EH}=0.75)$ and Amarelo $(\mathrm{PH}=1.56$ and $\mathrm{EH}=0.75)$ (Table 3$)$. The estimates of changes in the mean due to inbreeding showed positive unidirectional dominance for the two traits (Table 5). Rosa Claro had the highest degree of sensitivity to inbreeding, and Beija-Flor was the least sensitive. Beija-Flor also showed the smallest genetic variability within a population for the two characteristics.

Regarding the proportions of root lodged and stalk lodged plants, variance analysis indicated that there was genetic variability between populations and dominance $(\mathrm{F}=$ 2.36 and $\mathrm{F}=3.67$, significant at the $5 \%$ and $1 \%$ levels of probability for RL and SL, respectively). The GCA effects were significant for SL, while only significant RL variability was detected within populations (Table 2). Genes determining stalk lodging resistance were more frequent in the Amarelo population $(\mathrm{SL}=0.09)$ (Table 3$)$. For RL, the estimates of changes in the mean due to inbreeding indicated negative unidirectional dominance (Table 5). The most sensitive populations were Rosa Claro and Branco. BeijaFlor and Viçosa had less within-population genetic variability. Generally, the values of the proportions of root lodged and stalk lodged plants were not high in the parents, varying from 0.03 to 0.18 for RL, and from 0.09 to 0.12 for SL.

For the prolificacy index, there is evidence of genetic variability between populations and of dominance effects ( $\mathrm{F}=2.44$, significant at the $1 \%$ level of probability), although the GCA and SCA effects were nil, as were the changes in the population means due to inbreeding. No evidence of variability between and within populations was found for one hundred grains weight (Table 2).

\section{Conclusion}

Considering the obtained results, the importance of quality in popcorn populations, the commercial aspect of the grains and the proposal of the program developed by the Genetic Sector of the Federal University of Viçosa, the following conclusion was reached: the Beija-Flor and Viçosa populations should be used in intra- and inter-population (reciprocal recurrent selection) breeding programs and for the production of hybrids.

\section{References}

Cruz, CD and Vencovsky R (1989) Comparação de alguns métodos de análise dialélica. Rev Bras Genet 12:425-438.

Falconer DS and Mackay TFC (1996) Introduction to quantitative genetics. 4th ed. Longman, New York.

Gardner CO (1967) Simplified methods for estimating constants and computing sums of squares for a diallel cross analysis. Fitotec Latinoam 4:1-12.

Gardner CO and Eberhart SA (1966) Analysis and interpretation of the variety cross diallel and related populations. Biometrics 22:439-452.

Geraldi IO and Miranda Filho JB (1988) Adapted models for the analysis of combining ability of varieties in partial diallel crosses. Rev Bras Genet 11:419-430.

Graybill FA (1976) Theory and Application of the Linear Model. Duxbury Press, North Scituate, Massachusetts.

Griffing B (1956a) A generalized treatment of the use of diallel crosses in quantitative inheritance. Heredity 10:31-50.

Griffing B (1956b) Concept of general and specific combining ability in relation to diallel crossing system. Aust J Biol Sci 9:463-493.

Hayman BI (1954) The theory and analysis of diallel crosses. Genetics 39:789-809.

Hayman BI (1958) The theory and analysis of diallel crosses. II. Genetics 43:63-85.

Jinks JL and Hayman BI (1953) The analysis of diallel crosses. Maize Genet Cooperation News Lett 27:48-54.

Miranda Filho JB and Geraldi IO (1984) An adapted model for the analysis of partial diallel crosses. Rev Bras Genet 4:677688.

Searle SR (1971) Linear Models. John Wiley and Sons, New York.

Viana JMS, Cruz CD and Cardoso AA (1999) Theory and analysis of partial diallel crosses. Genet Mol Biol 22:591-599.

Viana, JMS (2000a) The parametric restrictions of the Gardner and Eberhart diallel analysis model: heterosis analysis. Genet Mol Biol 23:869-875.

Viana JMS (2000b) The parametric restrictions of the Griffing diallel analysis model: combining ability analysis. Genet Mol Biol 23:877-881.

Editor: Natal Antonio Vello 